\title{
Intertemporal Equity and Efficient Allocation of Resources*
}

\section{Tapan Mitra**}

November 2000

* I would like to thank Swapan Dasgupta for many useful conversations. An earlier version of this paper was presented at a conference on "General Equilibrium and Economic Growth" at Queen Mary and Westfield College, the University of London, in June, 2000. Comments from participants at the conference are gratefully acknowledged.

** 418 Uris Hall, Department of Economics, Cornell University, Ithaca, NY 14853, USA; Phone:(607) 255-4062; Fax Number:(607) 255-2818; E-mail address: tm19@cornell.edu 


\section{Introduction}

The purpose of this paper is to characterize efficient equitable paths in an infinite-horizon framework in terms of an investment rule.

This area of study originates with a paper by Solow (1974), who analyzed a capital accumulation model, with Cobb-Douglas technology, in the presence of an exhaustible resource. He was interested in the possibility of sustainable consumption levels in this context and, eschewing the use of the traditional discounted integral of utilities as a measure of welfare, concentrated attention on the welfare of the least well off generation. His choice of the objective was of the Rawlsian Maximin type, seeking to maximize the least consumption level that can be assured along growth paths from given initial resources. Such a path is efficient as well as equitable, where equity in this context means that the path maintains a constant consumption level at all dates. Subsequently, Hartwick (1977) made the interesting observation that a competitive equilibrium path, which follows the simple rule of thumb of investing the rents from the exhaustible resources used at each date, in the net accumulation of produced capital goods, is equitable. We shall refer to this investment rule as Hartwick's rule (HR). As Solow (1986, 1992) has observed, this is an intuitively appealing investment rule of maintaining the consumption potential of society, in a generalized sense, by replacing exhaustible resource stocks, which are used up, with produced capital goods of equal value.

It turns out that Hartwick's Rule has significance in a wider class of models than the special context in which it arose initially. In particular, Dixit, Hammond and Hoel (1980) recognized that Hartwick's Rule is really a statement that the valuation of net investment (including the dis-investment in the exhaustible resource) is zero at each date. They then proceeded to show in a general model of accumulation involving heterogenous capital goods 
(which could include various non-renewable resource stocks) that if the valuation of net investment is constant over time (the constant is not required to be zero) then this would ensure intertemporal equity (in the sense described above, but with "consumption" interpreted now as the utility based on a vector of consumption goods). Furthermore, this investment rule, which might justifiably be called the Dixit-Hammond-Hoel rule (DHH rule for short) was also a necessary condition for intertemporal equity along competitive paths.

This is an elegant characterization of competitive equitable paths. But it also naturally leads one to ask whether Hartwick's rule has any special significance. This question is prompted by the observation that in Solow's original exercise in the context of the exhaustible resource model, the maximin equitable paths do in fact satisfy Hartwick's rule, not just the DixitHammond-Hoel rule. There has been quite a bit of interest in this issue more recently; see Withagen and Asheim(1998) for references to some of the literature that has emerged.

Roughly speaking, the conjecture is that for competitive paths which are both equitable and efficient, Hartwick's Rule must hold. In the exhaustible resource model (but without the special structure of the Cobb-Douglas technology of Solow(1974)), a result like this was first noted by Dasgupta and Mitra(1983). However, their treatment of equity and efficiency was in the context of a discrete-time model, where Hartwick's rule does not hold in the original form but rather in a modified form. In the continuous time framework of this exhaustible resource model, Hartwick's rule does hold in its original form as a necessary condition along efficient equitable paths (see, for example, Hamilton (1995)).

Given these observations, Withagen and Asheim(1998) pose the right problem: "A question that naturally arises is whether the converse of Hartwick's rule holds in general in an 
economy with stationary instantaneous preferences and a stationary technology: Does an efficient constant utility path imply that the value of net investments equals zero at each point in time ?" Dixit,Hammond and Hoel (1980) attempted to answer this question, but they were only able to establish this under a "capital deepening" condition used by Burmeister and Turnovsky (1972), which is not easy to interpret. Withagen and Asheim (1998) themselves proceed to establish the result for efficient constant utility paths that are supported by positive utility discount factors having the property that the integral of the discount factors exists ; that is, for paths which are regular maximin in the sense of Burmeister and Hammond(1977). The difficulty is that with this restriction they cannot accomodate into their theory paths of the golden-rule variety, in neoclassical models of the Cass-Koopmans type, in which exhaustible resources are not essential factors in production. Their exercise, while generalizing results of Aronsson et.al. (1995), does not provide a complete answer to the question posed in their own paper.

The principal difficulty in settling this question appears to be the following. Hartwick's Rule is valid only in a continuous-time framework. To establish a "converse of Hartwick's rule", one must therefore have a suitable necessary condition for efficiency in a continuous-time framework. Unfortunately, the study of efficient allocation of resources has been confined almost exclusively to the discrete-time framework: the important characterizations of efficiency, due to Malinvaud (1953) and Cass(1972) are established in discrete-time models. The effort in obtaining these characterizations are serious enough even without the additional technical difficulties of the parallel continuous-time models. While there are some characterizations of efficiency in the continuous-time framework (see, for example, Majumdar(1972) for some of the important theorems), general results exclude the settings which allow for golden-rule type 
programs.

Actually, while obtaining a "complete characterization of efficiency" in a continuoustime framework is a worthwhile project, we can do with far less in the present context. What we really need to show is that (in a continuous-time model) competitive paths which are efficient satisfy a "terminal cost minimization" condition in the sense of Malinvaud (1953). In his discrete-time model, Malinvaud proved that this condition actually characterizes efficiency of competitive paths. However, the concept of "terminal cost minimization" involves comparison of the competitive path with paths which coincide with it (in its utility stream) from a certain time onwards. Thus, the characterization is not directly in terms of the given competitive path alone. This might explain why this condition, though clearly significant in the literature on efficient allocation of resources, has never been considered as important as the "transversality condition" criterion of efficiency of Malinvaud(1953), or the "rapidly deteriorating terms of trade condition" of inefficiency of Cass(1972). Nevertheless, for the present context, it holds center stage, because it provides precisely the information one needs to show the necessity of Hartwick's rule for efficient equitable paths.

The paper is organized as follows. In Section 2, we present a general model of intertemporal allocation in the continuous time framework, along the lines of Cass and Shell (1976). In Section 3, we discuss Hartwick's rule and its generalization by Dixit, Hammond and Hoel (1980). We then discuss these rules in the context of the standard one-sector neoclassical model, and provide an example where a competitive path which is equitable does not satisfy Hartwick's rule. In Section 4, we present the main results of the paper: (i) competitive paths which are efficient are shown to satisfy the "terminal cost minimization condition", and 
competitive paths which are equitable and efficient are shown to satisfy Hartwick's rule. In fact, Hartwick's Rule is seen to be simply the necessary first-order condition of terminal cost minimization along competitive equitable paths.

Given our results, Hartwick's rule takes on a significance that is quite distinct from the intertemporal equity issue. In fact, its role is seen to be to help identify inefficient equitable paths. Any competitive equitable path would satisfy the Dixit,Hammond,Hoel rule; but, if the (constant) value of investment were non-zero (that is, it violated Hartwick's Rule), it would be pronounced inefficient.

\section{Preliminaries}

\subsection{The Framework}

Consider a framework in which population and technology are unchanging, individuals at each date are identical in all respects (so one can think in terms of a single representative person at each date and ignore distribution considerations).

Denote by $\mathrm{k}_{\mathrm{i}} \geq 0$, the stock of the $\mathrm{i}^{\text {th }}$ capital good, where $\mathrm{i}=1, \ldots, \mathrm{n}$, and by $\mathrm{z}_{\mathrm{i}}$, the investment flow, net of depreciation, of the $\mathrm{i}^{\text {th }}$ capital good. Denote the vectors $\left(\mathrm{k}_{1}, \ldots, \mathrm{k}_{\mathrm{n}}\right)$ and $\left(\mathrm{z}_{1}, \ldots, \mathrm{z}_{\mathrm{n}}\right)$ by $\mathrm{k}$ and $\mathrm{z}$ respectively. The technology set, denoted by $\Lambda$, is a set of pairs $(\mathrm{z}, \mathrm{k})$ in $\mathbb{R}^{\mathrm{n}} \times \mathbb{R}^{\mathrm{n}}{ }_{+}$. By a typical point $(\mathrm{z}, \mathrm{k})$ of $\Lambda$ we understand that from capital input stock $\mathrm{k}$ it is technologically feasible to obtain the flows of net investments $\mathrm{z}$. The welfare function is denoted by a function $\mathrm{u}: \Lambda \rightarrow \mathbb{R}$. We shall make the following assumptions ${ }^{1}$ on $\Lambda$ and $\mathrm{u}$.

(A.1) $\Lambda$ is closed and convex; for each $\mathrm{k} \geq 0$, there is a $\mathrm{z}$ in $\mathbb{R}^{\mathrm{n}}$ such that $(\mathrm{z}, \mathrm{k}) \in \Lambda$. 
(A.2) Given any number $\xi>0$ there is a number $\eta>0$ such that $(\mathrm{z}, \mathrm{k}) \epsilon \Lambda$ and $|\mathrm{k}| \leq \xi$ implies $|\mathrm{u}(\mathrm{z}, \mathrm{k})| \leq \eta$ and $|\mathrm{z}| \leq \eta$.

(A.3) $\mathrm{u}$ is continuous on $\Lambda$ and twice continuously differentiable in the interior of $\Lambda$.

(A.4) $\mathrm{u}(\mathrm{z}, \mathrm{k}) \geq 0$ for $(\mathrm{z}, \mathrm{k}) \in \Lambda$; $\mathrm{u}$ is non-increasing in $\mathrm{z}$, i.e., $\mathrm{u}(\mathrm{z}, \mathrm{k}) \geq \mathrm{u}\left(\mathrm{z}^{\prime}, \mathrm{k}\right)$ if $(\mathrm{z}, \mathrm{k})$ and $\left(\mathrm{z}^{\prime}, \mathrm{k}\right) \in \Lambda$ and $\mathrm{z} \leq \mathrm{z}^{\prime}$.

(A.5) $\mathrm{u}$ is a concave function on $\Lambda$; for each $\mathrm{k} \gg>0, \mathrm{u}(\mathrm{z}, \mathrm{k})$ is a strictly concave function of $\mathrm{z}$; that is, if $\left(\mathrm{z}^{\prime}, \mathrm{k}\right)$ and $(\mathrm{z}, \mathrm{k})$ are in $\Lambda$ satisfying $\mathrm{z}^{\prime} \neq \mathrm{z}$ and $\lambda$ is a number satisfying $0<\lambda<1$, then $\mathrm{u}\left(\lambda \mathrm{z}+(1-\lambda) \mathrm{z}^{\prime}, \mathrm{k}\right)>\lambda \mathrm{u}(\mathrm{z}, \mathrm{k})+(1-\lambda) \mathrm{u}\left(\mathrm{z}^{\prime}, \mathrm{k}\right)$; in the interior of $\Lambda$, the matrix of second partials of $\mathrm{u}$ with respect to $\mathrm{z}, \partial^{2} \mathrm{u}(\mathrm{z}, \mathrm{k}) / \partial \mathrm{z}^{2}$, is negative definite.

Remark 2.1: For each $\mathrm{k} \geq 0$, defining the set $\Lambda(\mathrm{k})$ by: $\Lambda(\mathrm{k}) \equiv\{\mathrm{z}:(\mathrm{z}, \mathrm{k}) \in \Lambda\}$, we note that $\Lambda(\mathrm{k})$ is a non-empty, compact and convex subset of $\mathbb{R}^{\mathrm{n}} \times \mathbb{R}^{{ }^{\mathrm{n}}}$.

A path from initial stock $\mathrm{K}$ in $\mathbb{R}^{\mathrm{n}}{ }_{+}$is a pair of functions $(\mathrm{z}(\bullet), \mathrm{k}(\bullet))$, where $\mathrm{z}(\bullet):[0, \infty) \rightarrow$ $\mathbb{R}^{\mathrm{n}}$ and $\mathrm{k}(\bullet):[0, \infty) \rightarrow \mathbb{R}^{\mathrm{n}}{ }_{+}$, such that $\mathrm{k}(\bullet)$ is absolutely continuous and ${ }^{2}$

$(\mathrm{z}(\mathrm{t}), \mathrm{k}(\mathrm{t})) \in \Lambda$ for $\mathrm{t} \geq 0$, a.e.; $\mathrm{k}(\mathrm{t})=\mathrm{z}(\mathrm{t})$ for $\mathrm{t} \geq 0$, a.e.; and $\mathrm{k}(0)=\mathrm{K}$

Denote by $\mathfrak{s}(\mathrm{K})$ the set of programs from initial stock K. We shall assume:

(A.6) For each $\mathrm{K}$ in $\mathbb{R}^{\mathrm{n}}{ }_{+}$, $\Im(K)$ is non-empty.

A path $(\mathrm{z}(\mathrm{t}), \mathrm{k}(\mathrm{t}))$ from $\mathrm{K}$ is called equitable if $\mathrm{u}(\mathrm{z}(\mathrm{t}), \mathrm{k}(\mathrm{t}))$ is constant over time. It is called inefficient if there is another path $\left(\mathrm{z}^{\prime}(\mathrm{t}), \mathrm{k}^{\prime}(\mathrm{t})\right)$ from $\mathrm{K}$, such that $\mathrm{u}\left(\mathrm{z}^{\prime}(\mathrm{t}), \mathrm{k}^{\prime}(\mathrm{t})\right) \geq \mathrm{u}(\mathrm{z}(\mathrm{t}), \mathrm{k}(\mathrm{t}))$ for a.e. $\mathrm{t} \geq 0$, and denoting Lebesgue measure on the reals by $\lambda$,

$$
\lambda\left\{\mathrm{t}: \mathrm{u}\left(\mathrm{z}^{\prime}(\mathrm{t}), \mathrm{k}^{\prime}(\mathrm{t})\right)>\mathrm{u}(\mathrm{z}(\mathrm{t}), \mathrm{k}(\mathrm{t}))\right\}>0
$$


It is called efficient if it is not inefficient.

\subsection{Examples}

In this section we shall provide two examples of the framework described earlier. The examples will play a role in subsequent sections. They have not been chosen for their generality; various linear, as well as non-linear, multisector models which may be accomodated in the framework described earlier may be found in the examples discussed in Magill (1981).

Example 1: This is the well known one sector neoclassical growth model of the CassKoopmans type (see Cass (1965), Koopmans (1965)).

There is one good which is both the capital good and the consumption good. Labor is assumed to be constant over time. Let $\mathrm{G}: \mathbb{R}_{+} \rightarrow \mathbb{R}_{+}$denote the gross production function; a number $\delta$, satisfying $0<\delta<\infty$, denotes the constant exponential rate of depreciation of the capital stock; and w: $\mathbb{R}_{+} \rightarrow \mathbb{R}_{+}$denotes a cardinal welfare function. The functions $G$ and $w$ are assumed to satisfy the following properites:

(N.1) $\mathrm{G}(0)=0$; $\mathrm{G}$ is continuous on $\mathbb{R}_{+}$; $\mathrm{G}$ is twice continuously differentiable on $\mathbb{R}_{++}$; for $\mathrm{k}>0$, $\mathrm{G}^{\prime}(\mathrm{k})>0$ and $\mathrm{G}^{\prime \prime}(\mathrm{k}) \leq 0$; there is $\mathrm{k}^{\prime}>0$ such that for $\mathrm{k} \in\left(0, \mathrm{k}^{\prime}\right], \mathrm{G}^{\prime}(\mathrm{k})>\delta$; there is $\mathrm{k}^{\prime \prime}>0$ such that for $\mathrm{k} \in\left[\mathrm{k}^{\prime \prime}, \infty\right), \mathrm{G}^{\prime}(\mathrm{k})<\delta$.

(N.2) $\quad \mathrm{w}(0)=0 ; \mathrm{w}$ is continuous and concave on $\mathbb{R}_{+} ; \mathrm{w}$ is twice continuously differentiable on $\mathbb{R}_{++} ; \mathrm{w}^{\prime}(\mathrm{C})>0$ for all $\mathrm{C}>0 ; \mathrm{w}^{\prime \prime}(\mathrm{C})<0$ for all $\mathrm{C}>0 ; \mathrm{w}^{\prime}(\mathrm{C}) \rightarrow \infty$ as $\mathrm{C} \rightarrow 0$.

Remark 2.2: The technology set here is $\Lambda=\{(\mathrm{z}, \mathrm{k}): \mathrm{k} \geq 0 ; \mathrm{G}(\mathrm{k})-\delta \mathrm{k} \geq \mathrm{z} \geq-\delta \mathrm{k}\} ; \mathrm{u}: \Lambda \rightarrow \mathbb{R}_{+}$is given by the formula: $\mathrm{u}(\mathrm{z}, \mathrm{k})=\mathrm{w}(\mathrm{G}(\mathrm{k})-\delta \mathrm{k}-\mathrm{z})$, for $(\mathrm{z}, \mathrm{k}) \in \Lambda$; and, for $\left(\mathrm{z}^{\prime}, \mathrm{k}^{\prime}\right)$ in the interior of $\Lambda$, $\mathrm{u}$ is twice continuously differentiable, $\mathrm{u}_{1}\left(\mathrm{z}^{\prime}, \mathrm{k}^{\prime}\right)=-\mathrm{w}^{\prime}\left(\mathrm{C}^{\prime}\right)<0$ and $\mathrm{u}_{11}\left(\mathrm{z}^{\prime}, \mathrm{k}^{\prime}\right)=\mathrm{w}^{\prime \prime}\left(\mathrm{C}^{\prime}\right)<0$, where 
$\mathrm{C}^{\prime}=\mathrm{G}\left(\mathrm{k}^{\prime}\right)-\delta \mathrm{k}^{\prime}-\mathrm{z}^{\prime}>0$. It may be verified that Example 1 satisfies (A.1) to (A.3). Details may be found in Dasgupta and Mitra (1998).

Example 2: This is a model with one produced good, which serves as both the capital as well as the consumption good, and an exhaustible resource. Labor is assumed to be constant over time. The model described below is a standard one employed in the literature on optimal allocation of resources over time in the presence of an exhaustible resource (see for example Dasgupta and Heal (1974, 1979), Solow (1974)).

Denote by $\mathrm{k}_{1}$ the stock of augmentable capital good and by $\mathrm{k}_{2}$ the stock of the exhaustible resource. A number $\delta$, satisfying $0 \leq \delta<\infty$, denotes the constant exponential depreciation rate of augmentable capital. Let $\mathrm{G}: \mathbb{R}_{+}^{2} \rightarrow \mathbb{R}_{+}$denote the gross production function for the capital cum consumption good, using the capital input stock $\mathrm{k}_{1}$ and the flow of exhaustible resource used $\left(-z_{2}\right)$. It is assumed that the flow of resource use cannot exceed a maximum level denoted by $\mathrm{R}>0$. The output $\mathrm{G}\left(\mathrm{k}_{1}-\mathrm{z}_{2}\right)$ can be used to replace worn out capital (if any), $\delta \mathrm{k}_{1}$, to augment the capital stock through net investment, $\mathrm{z}_{1}$, or to provide consumption or utility (c) using a (welfare) function $\mathrm{w}: \mathbb{R}_{+} \rightarrow \mathbb{R}_{+}$. The following assumptions are made on $\mathrm{G}$ and $\mathrm{w}$.

(R.1) (i) $\mathrm{G}(0,0)=\mathrm{G}(0, \mathrm{y})=\mathrm{G}(\mathrm{x}, 0)=0$ for $\mathrm{x} \geq 0$ and $\mathrm{y} \geq 0$.

(ii) $\mathrm{G}$ is continuous, concave and nondecreasing on $\mathbb{R}^{2}$, and twice continuously differentiable on $\mathbb{R}_{++}^{2} ; \mathrm{G}_{1}(\mathrm{x}, \mathrm{y})>0, \mathrm{G}_{2}(\mathrm{x}, \mathrm{y})>0$ and $\mathrm{G}_{22}(\mathrm{x}, \mathrm{y})<0$ for $(\mathrm{x}, \mathrm{y})>>0$.

(R.2) $\quad \mathrm{w}(0)=0, \mathrm{w}$ is continuous and concave on $\mathbb{R}_{+} ; \mathrm{w}$ is twice continuously differentiable on $\mathbb{R}_{++} ; \mathrm{w}^{\prime}(\mathrm{C})>0$ and $\mathrm{w}^{\prime \prime}(\mathrm{C})<0$ for $\mathrm{C}>0 ; \mathrm{w}^{\prime}(\mathrm{C}) \rightarrow \infty$ as $\mathrm{C} \rightarrow 0$. 
The technology set here is $\Lambda=\left\{\left(\mathrm{z}_{1}, \mathrm{z}_{2}, \mathrm{k}_{1}, \mathrm{k}_{2}\right):\left(\mathrm{k}_{1}, \mathrm{k}_{2}\right) \geq 0 ;-\mathrm{R} \leq \mathrm{z}_{2} \leq 0 ; \mathrm{G}\left(\mathrm{k}_{1},-\mathrm{z}_{2}\right)-\delta \mathrm{k}_{1}>. \mathrm{z}_{1}\right.$ $\left.\geq-\delta \mathrm{k}_{1}\right\}$ and the formula for $\mathrm{u}: \Lambda \rightarrow \mathbb{R}_{+}$is: $\mathrm{u}\left(\mathrm{z}_{1}, \mathrm{z}_{2}, \mathrm{k}_{1}, \mathrm{k}_{2}\right)=\mathrm{w}\left(\mathrm{G}\left(\mathrm{k}_{1},-\mathrm{z}_{2}\right)-\delta \mathrm{k}_{1}-\mathrm{z}_{1}\right)$ for $\left(\mathrm{z}_{1}, \mathrm{z}_{2}, \mathrm{k}_{1}, \mathrm{k}_{2}\right) \in$ $\Lambda$. It may also be verified that Example 2 satisfies (A.1) to (A.3). Details may be found in Dasgupta and Mitra (1998).

\subsection{Competitive Paths}

We shall now elaborate what we mean by a time path of quantities and prices which evolve along an equilibrium of a competitive market economy, from an initial stock K. It would be convenient, for what follows, to introduce the following notation and concepts. Let $\mathrm{p}=\left(\mathrm{p}_{1}, \ldots, \mathrm{p}_{\mathrm{n}}\right)$ denote prices of the investment goods and q denote a positive weight on the utility. Define a function $\mathrm{H}: \mathbb{R}^{\mathrm{n}}{ }_{+} \times \mathbb{R}^{\mathrm{n}} \times \mathbb{R}_{++} \rightarrow \mathbb{R}$ by:

$$
\begin{array}{rr}
H(k, p, q)= & \operatorname{Max}[q u(z, k)+p z] \\
& \text { Subject to }(\mathrm{z}, \mathrm{k}) \in \Lambda
\end{array}
$$

By Remark 2.1, for each $\mathrm{k}$ in $\mathbb{R}^{\mathrm{n}}{ }_{+}, \Lambda(\mathrm{k})$ is non-empty and compact and so $\mathrm{H}(\mathrm{k}, \mathrm{p}, \mathrm{q})$ is well defined. Further, $\mathrm{H}$ is convex in $\mathrm{p}$ and $\mathrm{q}$, and since $\Lambda$ is convex, $\mathrm{H}$ is concave in $\mathrm{k}$.

By (A.5), for $\mathrm{k} \gg 0, \mathrm{u}(\mathrm{z}, \mathrm{k})$ is strictly concave in $\mathrm{z}$ and, therefore, there is a unique maximizing choice of investment, which solves (2.3). We can write this maximizing choice of $\mathrm{z}$ in (2.3) as a function $\mathrm{g}(\mathrm{k}, \mathrm{p}, \mathrm{q})$, that is, $\mathrm{g}: \mathbb{R}^{\mathrm{n}}{ }_{+} \times \mathbb{R}^{\mathrm{n}} \times \mathbb{R}_{++} \rightarrow \mathbb{R}^{\mathrm{n}}$ such that

$$
\mathrm{H}(\mathrm{k}, \mathrm{p}, \mathrm{q})=\mathrm{qu}(\mathrm{g}(\mathrm{k}, \mathrm{p}, \mathrm{q}))+\mathrm{pg}(\mathrm{k}, \mathrm{p}, \mathrm{q}) \text {, and }(\mathrm{g}(\mathrm{k}, \mathrm{p}, \mathrm{q}), \mathrm{k}) \in \Lambda
$$

Remark 2.3: For $\left(\mathrm{k}^{0}, \mathrm{p}^{0}, \mathrm{q}^{0}\right)$ such that $\mathrm{k}^{0}>>0$ and $\left(\mathrm{g}\left(\mathrm{k}^{0}, \mathrm{p}^{0}, \mathrm{q}^{0}\right), \mathrm{k}^{0}\right)$ is in the interior of $\Lambda$,

(i) $\quad \mathrm{p}^{0}+\mathrm{q}^{0} \partial \mathrm{u}\left(\mathrm{g}\left(\mathrm{k}^{0}, \mathrm{p}^{0}, \mathrm{q}^{0}\right), \mathrm{k}^{0}\right) / \partial \mathrm{z}=0$

(ii) By (A.3), the function $\mathrm{f}(\mathrm{k}, \mathrm{p}, \mathrm{q}, \mathrm{z}) \equiv \mathrm{p}+\mathrm{q} \partial \mathrm{y}(\mathrm{z}, \mathrm{k}) / \partial \mathrm{z}$ is defined in an open neighborhood around $\left(\mathrm{k}^{0}, \mathrm{p}^{0}, \mathrm{q}^{0}, \mathrm{~g}\left(\mathrm{k}^{0}, \mathrm{p}^{0}, \mathrm{q}^{0}\right)\right)$, is continuously differentiable, and its derivative 
matrix with respect to $\mathrm{z}$ is non-singular. Therefore, by the implicit function theorem, $g(k, p, q)$ is continuously differentiable with respect to $(k, p, q)$ in an open neighborhood $N$ of $\left(\mathrm{k}^{0}, \mathrm{p}^{0}, \mathrm{q}^{0}\right)$ and the range of $(\mathrm{g}(\mathrm{k}, \mathrm{p}, \mathrm{q}), \mathrm{k})$ for $(\mathrm{k}, \mathrm{p}, \mathrm{q})$ in $\mathrm{N}$, is in an open subset of $\Lambda$. It follows that in this neighborhood $\mathrm{N}$ of $\left(\mathrm{k}^{0}, \mathrm{p}^{0}, \mathrm{q}^{0}\right), \mathrm{H}$ is continuously differentiable and, by the envelope theorem,

$$
\begin{aligned}
& \partial \mathrm{H}(\mathrm{k}, \mathrm{p}, \mathrm{q}) / \partial \mathrm{p}=\mathrm{g}(\mathrm{k}, \mathrm{p}, \mathrm{q}), \partial \mathrm{H}(\mathrm{k}, \mathrm{p}, \mathrm{q}) / \partial \mathrm{q}=\mathrm{u}(\mathrm{g}(\mathrm{k}, \mathrm{p}, \mathrm{q}), \mathrm{k}) \\
& \partial \mathrm{H}(\mathrm{k}, \mathrm{p}, \mathrm{q}) / \partial \mathrm{k}=\partial \mathrm{u}(\mathrm{g}(\mathrm{k}, \mathrm{p}, \mathrm{q}), \mathrm{k}) / \partial \mathrm{k}
\end{aligned}
$$

A competitive path, is a path $(\mathrm{z}(\mathrm{t}), \mathrm{k}(\mathrm{t}))$ with associated prices, denoted by absolutely continuous functions of time $\mathrm{q}(\mathrm{t})$ and $\left(\mathrm{p}_{1}(\mathrm{t}), \ldots, \mathrm{p}_{\mathrm{n}}(\mathrm{t})\right) \equiv(\mathrm{p}(\mathrm{t}))$, with $\mathrm{q}(\mathrm{t})>0$ and $\mathrm{p}(\mathrm{t}) \geq 0$ for $\mathrm{t} \geq 0$, a.e., satisfying the following two conditions:

$$
\begin{aligned}
& \mathrm{q}(\mathrm{t}) \mathrm{u}(\mathrm{z}(\mathrm{t}), \mathrm{k}(\mathrm{t}))+\mathrm{p}(\mathrm{t}) \mathrm{z}(\mathrm{t})=\mathrm{H}(\mathrm{k}(\mathrm{t}), \mathrm{p}(\mathrm{t}), \mathrm{q}(\mathrm{t})) \text { for } \mathrm{t} \geq 0 \text {, a.e. } \\
& \dot{\mathrm{p}}(\mathrm{t})=-\partial \mathrm{H}(\mathrm{k}(\mathrm{t}), \mathrm{p}(\mathrm{t}), \mathrm{q}(\mathrm{t})) / \partial \mathrm{k} \text { for } \mathrm{t} \geq 0, \text { a.e. }
\end{aligned}
$$

Here, $\mathrm{p}(\mathrm{t})$ is the vector of present value prices of the investment goods, prevailing along a competitive path, at date $\mathrm{t}$. Use the notation $(\mathrm{z}(\mathrm{t}), \mathrm{k}(\mathrm{t}), \mathrm{p}(\mathrm{t}), \mathrm{q}(\mathrm{t}))$ to denote a competitive path with its associated prices. Along a competitive path, for each $t \geq 0$, we denote $H(k(t), p(t), q(t)$ ) by $\mathrm{y}(\mathrm{t})$; that is,

$$
y(t)=H(k(t), p(t), q(t)) \text { for } t \geq 0
$$

Interpreting utility as an output with present value price $q(t),(2.5)$ says that the maximum value of output achievable from capital stocks $\mathrm{k}(\mathrm{t})$ at the prices $\mathrm{p}(\mathrm{t}), \mathrm{q}(\mathrm{t})$, i.e. $\mathrm{H}(\mathrm{k}(\mathrm{t}), \mathrm{p}(\mathrm{t}), \mathrm{q}(\mathrm{t}))$ is realized along a competitive path, i.e.,

$$
y(t)=q(t) u(z(t), k(t))+p(t) z(t) \text { for } t \geq 0 \text {, a.e. }
$$

Equation (2.6) says that asset markets are in equilibrium; that is, no gains can be made by pure arbitrage [see Dorfman, Samuelson and Solow (1958), Weitzman (1976).] 
If $(\mathrm{z}(\bullet), \mathrm{k}(\bullet))$ is a path from $\mathrm{K}$ in $\mathbb{R}^{\mathrm{n}}{ }_{+}$, we shall say that it is interior if (i) $(\mathrm{z}(\mathrm{t}), \mathrm{k}(\mathrm{t}))$ is in the interior of $\Lambda$ in $\mathbb{R}^{\mathrm{n}} \times \mathbb{R}^{\mathrm{n}}$ for $\mathrm{t} \geq 0$, a.e., and (ii) $\mathrm{k}(\mathrm{t})>>0$ for $\mathrm{t} \geq 0$.

\section{Lemma 2.1:}

If $(\mathrm{z}(\mathrm{t}), \mathrm{k}(\mathrm{t}), \mathrm{p}(\mathrm{t}), \mathrm{q}(\mathrm{t}))$ is an interior competitive path from $\mathrm{K}$ in $\mathbb{R}^{\mathrm{n}}{ }_{++}$, then

(i) the function $y(t)$, defined in (2.7) is an absolutely continuous function of $t$; and

(ii) $\quad \dot{y}(t)=\dot{q}(t) u(z(t), k(t))$ for $t \geq 0$, a.e.

Proof: (i) Let $0 \leq \mathrm{a}<\mathrm{b}<\infty$ be given. For $\mathrm{t} \in[\mathrm{a}, \mathrm{b}]$, we have $\mathrm{y}(\mathrm{t})=(\mathrm{H}(\mathrm{k}(\mathrm{t}), \mathrm{p}(\mathrm{t}), \mathrm{q}(\mathrm{t}))$. Now $(\mathrm{k}(\mathrm{t}), \mathrm{p}(\mathrm{t}), \mathrm{q}(\mathrm{t}))$ are continuous on $[\mathrm{a}, \mathrm{b}]$, so we can find $0 \leq \mathrm{m} \leq \mathrm{M}<\infty$ such that for all $\mathrm{t} \in[\mathrm{a}, \mathrm{b}]$, $\mathrm{m} \leq \mathrm{k}_{\mathrm{i}}(\mathrm{t}) \leq \mathrm{M}$ for $\mathrm{i}=1, \ldots, \mathrm{n}, 0 \leq \mathrm{p}_{\mathrm{i}}(\mathrm{t}) \leq \mathrm{M}$ for $\mathrm{i}=1, \ldots, \mathrm{n}$, and $\mathrm{m} \leq \mathrm{q}(\mathrm{t}) \leq \mathrm{M}$. Since the competitive path is interior, we may choose $\mathrm{m}>0$. Thus, $\mathrm{E} \equiv[\mathrm{me}, \mathrm{Me}]$ is a compact subset in the interior of $\mathbb{R}^{{ }^{n}}$, where $e=(1, \ldots, 1)$ in $\mathbb{R}^{\mathrm{n}}$.

Let $\mathrm{t}_{1}, \mathrm{t}_{2}$ be arbitrary points in $[\mathrm{a}, \mathrm{b}]$. Then $\mathrm{y}\left(\mathrm{t}_{2}\right)-\mathrm{y}\left(\mathrm{t}_{1}\right)=\mathrm{H}\left(\mathrm{k}\left(\mathrm{t}_{2}\right), \mathrm{p}\left(\mathrm{t}_{2}\right), \mathrm{q}\left(\mathrm{t}_{2}\right)\right)-\mathrm{H}\left(\mathrm{k}\left(\mathrm{t}_{1}\right)\right.$, $\left.\mathrm{p}\left(\mathrm{t}_{1}\right), \mathrm{q}\left(\mathrm{t}_{1}\right)\right)=\mathrm{H}\left(\mathrm{k}\left(\mathrm{t}_{2}\right), \mathrm{p}\left(\mathrm{t}_{2}\right), \mathrm{q}\left(\mathrm{t}_{2}\right)\right)-\mathrm{H}\left(\mathrm{k}\left(\mathrm{t}_{1}\right), \mathrm{p}\left(\mathrm{t}_{2}\right), \mathrm{q}\left(\mathrm{t}_{2}\right)\right)+\mathrm{H}\left(\mathrm{k}\left(\mathrm{t}_{1}\right), \mathrm{p}\left(\mathrm{t}_{2}\right), \mathrm{q}\left(\mathrm{t}_{2}\right)\right)-\mathrm{H}\left(\mathrm{k}\left(\mathrm{t}_{1}\right), \mathrm{p}\left(\mathrm{t}_{1}\right)\right.$, $\left.\mathrm{q}\left(\mathrm{t}_{1}\right)\right)$. Thus, we have

$$
\begin{aligned}
& \left|\mathrm{y}\left(\mathrm{t}_{2}\right)-\mathrm{y}\left(\mathrm{t}_{1}\right)\right| \leq\left|\mathrm{H}\left(\mathrm{k}\left(\mathrm{t}_{2}\right), \mathrm{p}\left(\mathrm{t}_{2}\right), \mathrm{q}\left(\mathrm{t}_{2}\right)\right)-\mathrm{H}\left(\mathrm{k}\left(\mathrm{t}_{1}\right), \mathrm{p}\left(\mathrm{t}_{2}\right), \mathrm{q}\left(\mathrm{t}_{2}\right)\right)\right|+ \\
& \left|\mathrm{H}\left(\mathrm{k}\left(\mathrm{t}_{1}\right), \mathrm{p}\left(\mathrm{t}_{2}\right), \mathrm{q}\left(\mathrm{t}_{2}\right)\right)-\mathrm{H}\left(\mathrm{k}\left(\mathrm{t}_{1}\right), \mathrm{p}\left(\mathrm{t}_{1}\right), \mathrm{q}\left(\mathrm{t}_{1}\right)\right)\right|
\end{aligned}
$$

The function $\mathrm{h}(\mathrm{k})=\mathrm{H}\left(\mathrm{k}, \mathrm{p}\left(\mathrm{t}_{2}\right), \mathrm{q}\left(\mathrm{t}_{2}\right)\right)$ is a concave function on $\mathbb{R}^{\mathrm{n}}{ }_{+}$and, therefore, is

Lipschitz on the compact subset $\mathrm{E}$ in the interior of $\mathbb{R}^{{ }^{n}}{ }_{+}$, with Lipschitz constant, $\mathrm{L}_{1}>0$. Thus,

$$
\left|\mathrm{H}\left(\mathrm{k}\left(\mathrm{t}_{2}\right), \mathrm{p}\left(\mathrm{t}_{2}\right), \mathrm{q}\left(\mathrm{t}_{2}\right)\right)-\mathrm{H}\left(\mathrm{k}\left(\mathrm{t}_{1}\right), \mathrm{p}\left(\mathrm{t}_{2}\right), \mathrm{q}\left(\mathrm{t}_{2}\right)\right)\right| \leq \mathrm{L}_{1}\left|\mathrm{k}\left(\mathrm{t}_{2}\right)-\mathrm{k}\left(\mathrm{t}_{1}\right)\right|
$$

The function $\mathrm{g}(\mathrm{p}, \mathrm{q})=\mathrm{H}\left(\mathrm{k}\left(\mathrm{t}_{1}\right), \mathrm{p}, \mathrm{q}\right)$ is a convex function on $\mathbb{R}^{\mathrm{n}} \times \mathbb{R}_{++}$, and therefore, is Lipschitz on the compact set $\left[0, M_{e}\right] \times[m, M]$ in the interior of $\mathbb{R}^{\mathrm{n}} \times \mathbb{R}_{++}$, with Lipschitz constant, $\mathrm{L}_{2}>0$. Thus, 


$$
\left|\mathrm{H}\left(\mathrm{k}\left(\mathrm{t}_{1}\right), \mathrm{p}\left(\mathrm{t}_{2}\right), \mathrm{q}\left(\mathrm{t}_{2}\right)\right)-\mathrm{H}\left(\mathrm{k}\left(\mathrm{t}_{1}\right), \mathrm{p}\left(\mathrm{t}_{1}\right), \mathrm{q}\left(\mathrm{t}_{1}\right)\right)\right| \leq \mathrm{L}_{2}\left|\left(\mathrm{p}\left(\mathrm{t}_{2}\right), \mathrm{q}\left(\mathrm{t}_{2}\right)\right)-\left(\mathrm{p}\left(\mathrm{t}_{1}\right), \mathrm{q}\left(\mathrm{t}_{1}\right)\right)\right|
$$

Given any $\varepsilon>0$, there exists $\delta>0$ such that if $a_{1}, b_{1}, \ldots, a_{r}, b_{r}$ are numbers satisfying $\mathrm{a} \leq \mathrm{a}_{1}<\mathrm{b}_{1} \leq \mathrm{a}_{2}<\mathrm{b}_{2} \leq \ldots \leq \mathrm{a}_{\mathrm{r}}<\mathrm{b}_{\mathrm{r}} \leq \mathrm{b}$ and $\sum_{\mathrm{j}=1}^{\mathrm{r}}\left(\mathrm{b}_{\mathrm{j}}-\mathrm{a}_{\mathrm{j}}\right)<\delta$, then for all $\mathrm{i}=1, \ldots, \mathrm{n}, \sum_{\mathrm{j}=1}^{\mathrm{r}}\left|\mathrm{k}_{\mathrm{i}}\left(\mathrm{b}_{\mathrm{j}}\right)-\mathrm{k}_{\mathrm{i}}\left(\mathrm{a}_{\mathrm{j}}\right)\right|$ $<\left(\varepsilon / 3 n L_{1}\right)$, and for all $\mathrm{i}=1, \ldots, \mathrm{n}, \sum_{\mathrm{j}=1}^{\mathrm{r}}\left|\mathrm{p}_{\mathrm{i}}\left(\mathrm{b}_{\mathrm{j}}\right)-\mathrm{p}_{\mathrm{i}}\left(\mathrm{a}_{\mathrm{j}}\right)\right|<\left(\varepsilon / 3 \mathrm{~nL}_{2}\right)$, and $\left|\mathrm{q}\left(\mathrm{b}_{\mathrm{j}}\right)-\mathrm{q}\left(\mathrm{a}_{\mathrm{j}}\right)\right|<\left(\varepsilon / 3 \mathrm{~L}_{2}\right)$, since $\mathrm{k}$, $\mathrm{p}$ and $\mathrm{q}$ are absolutely continuous on [a,b]. Thus, using (2.9), (2.10) and (2.11), we have

$$
\sum_{\mathrm{j}=1}^{\mathrm{r}}\left|\mathrm{y}\left(\mathrm{b}_{\mathrm{j}}\right)-\mathrm{y}\left(\mathrm{a}_{\mathrm{j}}\right)\right| \leq \mathrm{L}_{1}\left(\varepsilon / 3 \mathrm{~L}_{1}\right)+\mathrm{L}_{2}\left(\varepsilon / 3 \mathrm{~L}_{2}\right)+\mathrm{L}_{2}\left(\varepsilon / 3 \mathrm{~L}_{2}\right)=\varepsilon
$$

which means that $y(t)$ is absolutely continuous on $[a, b]$.

(ii) Since $\mathrm{g}(\mathrm{k}, \mathrm{p}, \mathrm{q})$ solves the problem (2.3) for $\mathrm{k}>>0$, we can use condition (2.5) for a competitive path to obtain

$$
\mathrm{g}(\mathrm{k}(\mathrm{t}), \mathrm{p}(\mathrm{t}), \mathrm{q}(\mathrm{t}))=\mathrm{z}(\mathrm{t}) \quad \text { for } \mathrm{t} \geq 0 \text { a.e. }
$$

Since the path is interior, $(\mathrm{g}(\mathrm{k}(\mathrm{t}), \mathrm{p}(\mathrm{t}), \mathrm{q}(\mathrm{t})), \mathrm{k}(\mathrm{t}))$ is in the interior of $\Lambda$. By (i) above, $\mathrm{y}(\mathrm{t})$ is absolutely continuous, and so for $\mathrm{t} \geq 0$ a.e., $\mathrm{y}(\mathrm{t})$ is differentiable. Also, $\mathrm{k}(\mathrm{t}), \mathrm{p}(\mathrm{t})$ and $\mathrm{q}(\mathrm{t})$ are differentiable, and by Remark 2.3, $\mathrm{H}(\mathrm{k}, \mathrm{p}, \mathrm{q})$ is continuously differentiable at $(\mathrm{k}(\mathrm{t}), \mathrm{p}(\mathrm{t}), \mathrm{q}(\mathrm{t}))$. Thus, by differentiating (2.7), and using the formulae derived in Remark 2.3,

$$
\begin{aligned}
\dot{\mathrm{y}}(\mathrm{t}) \quad & =[\partial \mathrm{H}(\mathrm{k}(\mathrm{t}), \mathrm{p}(\mathrm{t}), \mathrm{q}(\mathrm{t})) / \partial \mathrm{k}] \dot{\mathrm{k}}(\mathrm{t})+[\partial \mathrm{H}(\mathrm{k}(\mathrm{t}), \mathrm{p}(\mathrm{t}), \mathrm{q}(\mathrm{t})) / \partial \mathrm{p}] \dot{\mathrm{p}}(\mathrm{t}) \\
& +[\partial \mathrm{H}(\mathrm{k}(\mathrm{t}), \mathrm{p}(\mathrm{t}), \mathrm{q}(\mathrm{t})) / \partial \mathrm{q}] \dot{\mathrm{q}}(\mathrm{t})=[\partial \mathrm{H}(\mathrm{k}(\mathrm{t}), \mathrm{p}(\mathrm{t}), \mathrm{q}(\mathrm{t})) / \partial \mathrm{k}] \dot{\mathrm{k}}(\mathrm{t}) \\
& +\mathrm{g}(\mathrm{k}(\mathrm{t}), \mathrm{p}(\mathrm{t}), \mathrm{q}(\mathrm{t})) \dot{\mathrm{p}}(\mathrm{t})+\dot{\mathrm{q}}(\mathrm{t}) \mathrm{u}(\mathrm{z}(\mathrm{t}), \mathrm{k}(\mathrm{t})) \text { for } \mathrm{t} \geq 0 \text {, a.e. }
\end{aligned}
$$

Thus, we obtain

$$
\dot{\mathrm{y}}(\mathrm{t})=[\partial \mathrm{H}(\mathrm{k}(\mathrm{t}), \mathrm{p}(\mathrm{t}), \mathrm{q}(\mathrm{t})) / \partial \mathrm{k}] \dot{\mathrm{k}}(\mathrm{t})+\dot{\mathrm{k}}(\mathrm{t}) \dot{\mathrm{p}}(\mathrm{t})+\dot{\mathrm{q}}(\mathrm{t}) \mathrm{u}(\mathrm{z}(\mathrm{t}), \mathrm{k}(\mathrm{t})) \text { for } \mathrm{t} \geq 0 \text {, a.e. }
$$

Combining condition (2.6) for a competitive path with (2.13), we have

$$
\dot{y}(t)=\dot{q}(t) u(z(t), k(t)) \text { for } t \geq 0 \text {, a.e. }
$$


which establishes (ii). //

\section{A Characterization of Equitable Paths}

\subsection{Hartwick's Rule}

In the context of the exhaustible resource model, described in Example 2 of Section 2, the competitive conditions (2.5) and (2.6) amount to two familiar rules: (i) Hotelling's Rule on the allocation of an exhaustible resource over time, and (ii) Ramsey's Rule on the allocation of consumption over time.

We can see this as follows. An interior competitive path $(\mathrm{z}(\mathrm{t}), \mathrm{k}(\mathrm{t}), \mathrm{p}(\mathrm{t}), \mathrm{q}(\mathrm{t}))$ satisfies:

$$
\begin{aligned}
\mathrm{H}(\mathrm{k}(\mathrm{t}), \mathrm{p}(\mathrm{t}), \mathrm{q}(\mathrm{t}))= & \max \mathrm{q}(\mathrm{t}) \mathrm{w}\left[\mathrm{G}\left(\mathrm{k}_{1}(\mathrm{t}), \mathrm{r}\right)-\delta \mathrm{k}_{1}(\mathrm{t})-\mathrm{z}_{1}\right]+\mathrm{p}_{1}(\mathrm{t}) \mathrm{z}_{1}+\mathrm{p}_{2}(\mathrm{t})(-\mathrm{r}) \\
& \text { subject to }\left(\mathrm{z}_{1},-\mathrm{r}, \mathrm{k}_{1}(\mathrm{t}), \mathrm{k}_{2}(\mathrm{t})\right) \in \Lambda
\end{aligned}
$$

where we have written $r$ (the exhaustible resource use) for $\left(-z_{2}\right)$.

Using the first-order conditions for an interior maximum, we get

$$
\begin{gathered}
\mathrm{q}(\mathrm{t}) \mathrm{w}^{\prime}(\mathrm{c}(\mathrm{t}))(-1)+\mathrm{p}_{1}(\mathrm{t})=0 \text { for } \mathrm{t} \geq 0 \text { a.e. } \\
\mathrm{q}(\mathrm{t}) \mathrm{w}^{\prime}(\mathrm{c}(\mathrm{t}))\left[\mathrm{G}_{2}\left(\mathrm{k}_{1}(\mathrm{t}), \mathrm{r}(\mathrm{t})\right)\right]-\mathrm{p}_{2}(\mathrm{t})=0 \text { for } \mathrm{t} \geq 0 \text { a.e. }
\end{gathered}
$$

Also, by the envelope theorem, we have

$$
\begin{gathered}
\partial \mathrm{H}(\mathrm{k}(\mathrm{t}), \mathrm{p}(\mathrm{t}), \mathrm{q}(\mathrm{t})) / \partial \mathrm{k}_{1}=\mathrm{q}(\mathrm{t}) \mathrm{w}^{\prime}(\mathrm{c}(\mathrm{t}))\left[\mathrm{G}_{1}\left(\mathrm{k}_{1}(\mathrm{t}), \mathrm{r}(\mathrm{t})\right)-\delta\right] \text { for } \mathrm{t} \geq 0 \text { a.e. } \\
\partial \mathrm{H}(\mathrm{k}(\mathrm{t}), \mathrm{p}(\mathrm{t}), \mathrm{q}(\mathrm{t})) / \partial \mathrm{k}_{2}=0 \text { for } \mathrm{t} \geq 0 \text { a.e. }
\end{gathered}
$$

Thus, using condition (2.6) of a competitive path, we have

$$
\begin{array}{r}
\dot{\mathrm{p}}_{1}(\mathrm{t})=-\mathrm{q}(\mathrm{t}) \mathrm{w}^{\prime}(\mathrm{c}(\mathrm{t}))\left[\mathrm{G}_{1}\left(\mathrm{k}_{1}(\mathrm{t}), \mathrm{r}(\mathrm{t})\right)-\delta\right] \quad \text { for } \mathrm{t} \geq 0 \text { a.e. } \\
\dot{\mathrm{p}}_{2}(\mathrm{t})=0 \quad \text { for } \mathrm{t} \geq 0 \text { a.e. }
\end{array}
$$

We can use (3.1) and (3.5) to study the price path of the augmentable capital good:

$$
\left[\dot{p}_{1}(t) / p_{1}(t)\right]=\left[G_{1}\left(k_{1}(t), r(t)\right)-\delta\right] \text { for } t \geq 0 \text { a.e. }
$$


The price of the exhaustible resource is related to that of the augmentable good through (3.1) and (3.2):

$$
\mathrm{p}_{2}(\mathrm{t})=\mathrm{p}_{1}(\mathrm{t}) \mathrm{G}_{2}\left(\mathrm{k}_{1}(\mathrm{t}), \mathrm{r}(\mathrm{t})\right) \text { for } \mathrm{t} \geq 0 \text { a.e. }
$$

Differentiating (3.8) with respect to t, and using (3.6), we get:

$$
0=\dot{\mathrm{p}}_{2}(\mathrm{t})=\dot{\mathrm{p}}_{1}(\mathrm{t}) \mathrm{G}_{2}\left(\mathrm{k}_{1}(\mathrm{t}), \mathrm{r}(\mathrm{t})\right)+\dot{\mathrm{G}}_{2}\left(\mathrm{k}_{1}(\mathrm{t}), \mathrm{r}(\mathrm{t})\right) \mathrm{p}_{1}(\mathrm{t})
$$

which can be used with (3.7) to get

$$
\left[\dot{\mathrm{G}}_{2}\left(\mathrm{k}_{1}(\mathrm{t}), \mathrm{r}(\mathrm{t})\right) / \mathrm{G}_{2}\left(\mathrm{k}_{1}(\mathrm{t}), \mathrm{r}(\mathrm{t})\right)\right]=-\left[\dot{\mathrm{p}}_{1}(\mathrm{t}) / \mathrm{p}_{1}(\mathrm{t})\right]=\left[\mathrm{G}_{1}\left(\mathrm{k}_{1}(\mathrm{t}), \mathrm{r}(\mathrm{t})\right)-\delta\right] \text { for } \mathrm{t} \geq 0 \text {, a.e. }
$$

which indicates that the rate of return on the two capital goods (the augmentable and the nonrenewable one) are equalized. This is known as Hotelling's rule.

The version of Ramsey's rule that emerges in this context can be derived by differentiating (3.1):

$$
\dot{\mathrm{p}}_{1}(\mathrm{t})=\dot{\mathrm{q}}(\mathrm{t}) \mathrm{w}^{\prime}(\mathrm{c}(\mathrm{t}))+\mathrm{q}(\mathrm{t}) \dot{\mathrm{w}}^{\prime}(\mathrm{c}(\mathrm{t}))
$$

and then combining (3.1) and (3.10) with (3.7) to yield:

$$
-\left[\dot{\mathrm{w}}^{\prime}(\mathrm{c}(\mathrm{t})) / \mathrm{w}^{\prime}(\mathrm{c}(\mathrm{t}))\right]=[\dot{\mathrm{q}}(\mathrm{t}) / \mathrm{q}(\mathrm{t})]+\left[\mathrm{G}_{1}\left(\mathrm{k}_{1}(\mathrm{t}), \mathrm{r}(\mathrm{t})\right)-\delta\right]
$$

[If the utility weights, $\mathrm{q}(\mathrm{t})$, happen to be exponential, (3.11) yields the standard Ramsey-Euler equation of optimal growth theory with exponential discounting.]

Given concavity of the production and welfare functions, the Hotelling Rule (3.9) and the Ramsey Rule (3.11) in fact characterize competitive paths in this framework.

Hartwick (1977) made the observation that if along a competitive path one invests resource rents in the accumulation of the (augmentable) capital good, that is:

$$
\dot{\mathrm{k}}_{1}(\mathrm{t})=\mathrm{z}_{1}(\mathrm{t})=\mathrm{r}(\mathrm{t}) \mathrm{G}_{2}\left(\mathrm{k}_{1}(\mathrm{t}), \mathrm{r}(\mathrm{t})\right) \text { for } \mathrm{t} \geq 0 \text { a.e. }
$$

then the path is equitable: 
We refer to (3.12) as Hartwick's (investment) rule.

Hartwick's observation may be seen as follows. Using the feasibility condition:

$$
\mathrm{c}(\mathrm{t})=\mathrm{G}\left(\mathrm{k}_{1}(\mathrm{t}), \mathrm{r}(\mathrm{t})\right)-\delta \mathrm{k}_{1}(\mathrm{t})-\mathrm{z}_{1}(\mathrm{t})
$$

and Hartwick's rule (3.12), we get

$$
\mathrm{c}(\mathrm{t})=\mathrm{G}\left(\mathrm{k}_{1}(\mathrm{t}), \mathrm{r}(\mathrm{t})\right)-\delta \mathrm{k}_{1}(\mathrm{t})-\mathrm{r}(\mathrm{t}) \mathrm{G}_{2}\left(\mathrm{k}_{1}(\mathrm{t}), \mathrm{r}(\mathrm{t})\right) \text { for } \mathrm{t} \geq 0 \text {, a.e. }
$$

Differentiating (3.14), one obtains

$$
\begin{aligned}
\dot{\mathrm{c}}(\mathrm{t})= & \mathrm{G}_{1}\left(\mathrm{k}_{1}(\mathrm{t}), \mathrm{r}(\mathrm{t})\right) \dot{\mathrm{k}}_{1}(\mathrm{t})+\mathrm{G}_{2}\left(\mathrm{k}_{1}(\mathrm{t}), \mathrm{r}(\mathrm{t})\right) \dot{\mathrm{r}}(\mathrm{t}) \\
& -\delta \dot{\mathrm{k}}_{1}(\mathrm{t})-\mathrm{r}(\mathrm{t}) \dot{\mathrm{G}}_{2}\left(\mathrm{k}_{1}(\mathrm{t}), \mathrm{r}(\mathrm{t})-\dot{\mathrm{r}}(\mathrm{t}) \mathrm{G}_{2}\left(\mathrm{k}_{1}(\mathrm{t}), \mathrm{r}(\mathrm{t})\right)\right. \\
= & {\left[\mathrm{G}_{1}\left(\mathrm{k}_{1}(\mathrm{t}), \mathrm{r}(\mathrm{t})-\delta\right] \dot{\mathrm{k}}_{1}(\mathrm{t})-\mathrm{r}(\mathrm{t}) \dot{\mathrm{G}}_{2}\left(\mathrm{k}_{1}(\mathrm{t}), \mathrm{r}(\mathrm{t})\right)\right.} \\
= & {\left[\mathrm{G}_{1}\left(\mathrm{k}_{1}(\mathrm{t}), \mathrm{r}(\mathrm{t})\right)-\delta\right] \dot{\mathrm{k}}_{1}(\mathrm{t})-\left[\dot{\mathrm{G}}_{2}\left(\mathrm{k}_{1}(\mathrm{t}), \mathrm{r}(\mathrm{t})\right) / \mathrm{G}_{2}\left(\mathrm{k}_{1}(\mathrm{t}), \mathrm{r}(\mathrm{t})\right)\right] \mathrm{r}(\mathrm{t}) \dot{\mathrm{G}}_{2}\left(\mathrm{k}_{1}(\mathrm{t}), \mathrm{r}(\mathrm{t})\right) }
\end{aligned}
$$

Using Hartwick's rule (3.12) again, we get

$$
\dot{\mathrm{c}}(\mathrm{t})=\left\{\left[\mathrm{G}_{1}(\mathrm{k}(\mathrm{t}), \mathrm{r}(\mathrm{t}))-\delta\right]-\left[\dot{\mathrm{G}}_{2}\left(\mathrm{k}_{1}(\mathrm{t}), \mathrm{r}(\mathrm{t})\right) / \mathrm{G}_{2}\left(\mathrm{k}_{1}(\mathrm{t}), \mathrm{r}(\mathrm{t})\right)\right]\right\} \dot{\mathrm{k}}_{1}(\mathrm{t})
$$

which yields $\dot{\mathrm{c}}(\mathrm{t})=0$ by using Hotelling's Rule (3.9). This establishes (3.13); that is, intertemporal equity.

\subsection{Dixit, Hammond and Hoel's Result}

Dixit, Hammond, and Hoel (1980) observed that Hartwick's rule could be restated as the condition that the total value of investment in all capital goods is zero:

$$
\mathrm{p}(\mathrm{t}) \dot{\mathrm{k}}(\mathrm{t})=0
$$

In the context of the exhaustible resource model, we have, by using (3.8):

$$
\mathrm{p}(\mathrm{t}) \dot{\mathrm{k}}(\mathrm{t})=\mathrm{p}_{1} \dot{\mathrm{k}}_{1}(\mathrm{t})+\mathrm{p}_{2}(\mathrm{t})(-\mathrm{r}(\mathrm{t}))=\mathrm{p}_{1}(\mathrm{t})\left[\dot{\mathrm{k}}_{1}(\mathrm{t})-\mathrm{r}(\mathrm{t}) \mathrm{G}_{2}\left(\mathrm{k}_{1}(\mathrm{t}), \mathrm{r}(\mathrm{t})\right)\right]
$$

so that (3.15) is equivalent to (3.12). 
The question arises whether Hartwick's rule, in the form (3.15), for general capital accumulation models with heterogenous capital goods, characterizes intertemporal equity along competitive paths. The answer is that a weaker condition than (3.15) actually provides such a characterization. This weaker condition, which can be called the Dixit-Hammond-Hoel rule is that the value of investment along a competitive path, $\mathrm{p}(\mathrm{t}) \mathrm{z}(\mathrm{t})$, is constant over time.

We formally state and prove this result below.

\section{Proposition 3.1:}

An interior competitive path $(\mathrm{z}(\mathrm{t}), \mathrm{k}(\mathrm{t}), \mathrm{p}(\mathrm{t}), \mathrm{q}(\mathrm{t}))$ from $\mathrm{K}$ in $\mathbb{R}_{++}^{\mathrm{n}}$ is equitable iff

$$
\mathrm{I}(\mathrm{t}) \equiv \mathrm{p}(\mathrm{t}) \mathrm{z}(\mathrm{t}) \text { is constant over time }
$$

Proof: Since the competitive path is interior, we have from Lemma 2.1 (ii)

$$
\dot{y}(t)=\dot{q}(t) u(z(t), k(t)) \text { for } \mathrm{t} \geq 0 \text { a.e. }
$$

Differentiating (2.8), we get

$$
\dot{\mathrm{y}}(\mathrm{t})=\mathrm{q}(\mathrm{t}) \dot{\mathrm{u}}(\mathrm{z}(\mathrm{t}), \mathrm{k}(\mathrm{t}))+\dot{\mathrm{q}}(\mathrm{t}) \mathrm{u}(\mathrm{z}(\mathrm{t}), \mathrm{k}(\mathrm{t}))+\dot{\mathrm{I}}(\mathrm{t}) \quad \text { for } \mathrm{t} \geq 0 \text { a.e. }
$$

Using (3.17) and (3.18) we obtain

$$
\dot{I}(t)=-q(t) \dot{u}(z(t), k(t)) \text { for } t \geq 0 \text { a.e. }
$$

Clearly (3.19) yields the equivalence of $\dot{\mathrm{u}}(\mathrm{z}(\mathrm{t}), \mathrm{k}(\mathrm{t}))=0$ and $\dot{\mathrm{I}}(\mathrm{t})=0$ (since $\mathrm{q}(\mathrm{t})>0)$. $\quad / /$

\subsection{An Example}

We now indicate, in an example, that Hartwick's rule can be violated for an interior competitive path which is equitable, so that Hartwick's rule is, in general, different from the Dixit-Hammond-Hoel rule, and therefore HR does not characterize equitable competitive paths.

Our discussion will be based on Example 1 of Section 2, the familiar one-sector neoclassical model of growth. 
The function $[\mathrm{G}(\mathrm{k})-\delta(\mathrm{k})]$ is maximized at a unique point, $\mathrm{k}^{*}$, among all $\mathrm{k} \in[0, \infty)$, and $0<\mathrm{k}^{*}<\infty$. By the assumptions on $\mathrm{G}$ and $\delta,\left[\mathrm{G}\left(\mathrm{k}^{*}\right)-\delta \mathrm{k}^{*}\right]>0$ and is denoted by $\mathrm{C}^{*}$. Then $\left(\mathrm{k}^{*}, \mathrm{C}^{*}\right)$ denotes the golden-rule capital and consumption levels, respectively. There is a unique point, $\overline{\mathrm{k}}$, in $(0, \infty)$ where $\mathrm{G}(\overline{\mathrm{k}})=\delta \overline{\mathrm{k}}$. One can check that $\mathrm{k}^{*}<\overline{\mathrm{k}}<\infty ; \overline{\mathrm{k}}$ is the maximum sustainable stock.

Let the initial capital stock, $\mathrm{K}$, be in $\left(\mathrm{k}^{*}, \overline{\mathrm{k}}\right)$. Consider the differential equation:

$$
\dot{\mathrm{k}}(\mathrm{t})=\mathrm{G}(\mathrm{k}(\mathrm{t}))-\delta \mathrm{k}(\mathrm{t})-\mathrm{C}^{*}, \mathrm{k}(0)=\mathrm{K} \in\left(\mathrm{k}^{*}, \overline{\mathrm{k}}\right)
$$

It can be checked that there is a unique solution $(\mathrm{k}(\mathrm{t}))$ to this differential equation, and $(\mathrm{k}(\mathrm{t}))$ has the following properties:

(i) $\mathrm{k}^{*}<\mathrm{k}(\mathrm{t})<\mathrm{K}$ for $\mathrm{t} \geq 0$; (ii) $-\delta \mathrm{k}(\mathrm{t})<\mathrm{k}(\mathrm{t})<0$ for $\mathrm{t} \geq 0$

Defining $\mathrm{z}(\mathrm{t})=\dot{\mathrm{k}}(\mathrm{t})$ for $\mathrm{t} \geq 0$, we see that $(\mathrm{z}(\mathrm{t}), \mathrm{k}(\mathrm{t}))$ is an interior path from $\mathrm{K}$, and $\mathrm{u}(\mathrm{z}(\mathrm{t})$, $\mathrm{k}(\mathrm{t}))=\mathrm{w}\left(\mathrm{C}^{*}\right)$ for $\mathrm{t} \geq 0$. Thus, $(\mathrm{z}(\mathrm{t}), \mathrm{k}(\mathrm{t}))$ is an equitable path.

Let us define a function $\mathrm{p}(\mathrm{t})$ by

$$
\mathrm{p}(\mathrm{t})=\exp \left[\int_{0}^{\mathrm{t}}\left(\delta-\mathrm{G}^{\prime}(\mathrm{k}(\mathrm{s}))\right) \mathrm{ds}\right]
$$

then $\mathrm{p}(0)=1$ and $\mathrm{p}(\mathrm{t})$ is increasing with $\mathrm{t}$. Denoting $\left[\mathrm{p}(\mathrm{t}) / \mathrm{w}^{\prime}\left(\mathrm{C}^{*}\right)\right]$ by $\mathrm{q}(\mathrm{t})$, it is straightforward to check that $(\mathrm{z}(\mathrm{t}), \mathrm{k}(\mathrm{t}), \mathrm{p}(\mathrm{t}), \mathrm{q}(\mathrm{t}))$ is an interior competitive path from $\mathrm{K}$.

Since $\dot{k}(t)<0$, it is clear that

$$
\mathrm{p}(\mathrm{t}) \dot{\mathrm{k}}(\mathrm{t})<0 \quad \text { for } \mathrm{t} \geq 0
$$

so Hartwick's rule is violated on this competitive equitable path.

The competitive equitable path which we have constructed is clearly inefficient. To see this, define $\mathrm{T}$ by:

$$
\left(\mathrm{k}^{*} / \mathrm{K}\right)=1 / \mathrm{e}^{\delta \mathrm{T}}
$$

Then, define the function $\mathrm{k}^{\prime}(\mathrm{t})$ for $0 \leq \mathrm{t} \leq \mathrm{T}$ by 


$$
\mathrm{k}^{\prime}(\mathrm{t})=\mathrm{K} / \mathrm{e}^{\mathrm{\delta t}}
$$

and $\mathrm{k}^{\prime}(\mathrm{t})=\mathrm{k}^{*}$ for $\mathrm{t}>\mathrm{T}$. Then denoting $\dot{\mathrm{k}}^{\prime}(\mathrm{t})$ by $\mathrm{z}^{\prime}(\mathrm{t})$ for all $\mathrm{t} \neq \mathrm{T},\left(\mathrm{z}^{\prime}(\mathrm{t}), \mathrm{k}^{\prime}(\mathrm{t})\right)$ is a path from $\mathrm{K}$, which satisfies (see Figure 3):

$$
\mathrm{G}\left(\mathrm{k}^{\prime}(\mathrm{t})\right)-\delta \mathrm{k}^{\prime}(\mathrm{t})-\mathrm{k}^{\prime}(\mathrm{t})>\mathrm{C}^{*} \quad \text { for } 0 \leq \mathrm{t}<\mathrm{T}
$$

and $G\left(k^{\prime}(t)\right)-\delta k^{\prime}(t)-\dot{k}^{\prime}(t)=C^{*}$ for $t>T$. Thus, $(z(t), k(t))$ could not be efficient.

\section{A Characterization of Efficient Equitable Paths}

Given the result of Dixit, Hammond and Hoel (1980) discussed in Section 3b, and the example of Section 3c, it is clear that Hartwick's rule does not characterize competitive equitable paths. In this case, what precisely is the significance of Hartwick's rule?

The example of Section 3c seems to point in the following direction. If along a competitive equitable path, Hartwick's rule is not satisfied, then the path is intertemporally inefficient. If this were true in general, then Hartwick's rule would take on a significance that is quite distinct from the intertemporal equity issue. In fact, its role then would be to help identify inefficient equitable paths. Any competitive equitable path would satisfy the DHH rule; but, if the (constant) value of investment were non-zero, it would be pronounced inefficient.

A word of caution: we are not saying that Hartwick's rule will identify efficient paths. It is possible for a competitive equitable path to satisfy HR and still be inefficient. [One only needs to consider a stationary path in the neoclassical one-sector model, with the stationary capital stock exceeding the golden-rule capital stock.]

We proceed, in this section, to show that the lesson of the example of Section $3 \mathrm{c}$ can be fully generalized. But such a demonstration clearly requires a convenient necessary condition of 
efficient paths, which would yield Hartwick's rule when the path was also equitable. Absent any such general necessary condition in continuous time models, we have to develop one. This is accomplished in Proposition 4.1. The result on intertemporal efficiency is then used in Theorem 4.1 to derive Hartwick's rule as a necessary condition for efficient equitable paths.

The basic necessary condition for competitive efficiency that we establish is "terminal cost minimization", a concept due to Malinvaud (1953). In fact, in his general discrete-time model, Malinvaud characterizes competitive efficiency in terms of this condition.

The concept of terminal cost minimization is explained as follows. Consider a competitive efficient path $(\mathrm{z}(\mathrm{t}), \mathrm{k}(\mathrm{t}), \mathrm{p}(\mathrm{t}), \mathrm{q}(\mathrm{t}))$, and consider any instant of time, $\mathrm{T}>0$. Then for any path $\left(\mathrm{z}^{\prime}(\mathrm{t}), \mathrm{k}^{\prime}(\mathrm{t})\right)$ which maintains the same utility stream as $(\mathrm{z}(\mathrm{t}), \mathrm{k}(\mathrm{t}))$ from $\mathrm{T}$ onwards (that is, $\mathrm{u}\left(\mathrm{z}^{\prime}(\mathrm{t}), \mathrm{k}^{\prime}(\mathrm{t})\right)=\mathrm{u}(\mathrm{z}(\mathrm{t}), \mathrm{k}(\mathrm{t}))$ for $\mathrm{t} \geq \mathrm{T}$ a.e.), we must have the "terminal cost" of the capital stocks at $\mathrm{T}$ on the path $\left(\mathrm{z}^{\prime}(\mathrm{t}), \mathrm{k}^{\prime}(\mathrm{t})\right)$ at least as high as on the path $(\mathrm{z}(\mathrm{t}), \mathrm{k}(\mathrm{t}))$ (that is, $\mathrm{p}(\mathrm{T}) \mathrm{k}^{\prime}(\mathrm{T}) \geq$ $\mathrm{p}(\mathrm{T}) \mathrm{k}(\mathrm{T}))$. And this property is true for an arbitrary $\mathrm{T}>0$.

Then reason that this is just the right concept is establishing the converse of Hartwick's rule is the following. For a competitive efficient path $(\mathrm{z}(\mathrm{t}), \mathrm{k}(\mathrm{t}), \mathrm{p}(\mathrm{t}), \mathrm{q}(\mathrm{t}))$ which also happens to be equitable, the "comparison paths" in the above paragraph can be taken to be the original path, but shifted forward in time or backward in time (by any small fixed time interval, $\varepsilon$ ). Terminal cost minimization will then imply that for each $\mathrm{T}>0$,

and

$$
\begin{aligned}
& \mathrm{p}(\mathrm{T}) \mathrm{k}(\mathrm{T}) \leq \mathrm{p}(\mathrm{T}) \mathrm{k}(\mathrm{T}+\varepsilon) \\
& \mathrm{p}(\mathrm{T}) \mathrm{k}(\mathrm{T}) \leq \mathrm{p}(\mathrm{T}) \mathrm{k}(\mathrm{T}-\varepsilon)
\end{aligned}
$$

That is $\mathrm{p}(\mathrm{T}) \mathrm{k}(S)$ is minimized at T among all $S$ in a neighborhood of T. Then Hartwick's Rule

$$
\mathrm{p}(\mathrm{T}) \dot{\mathrm{k}}(\mathrm{T})=0
$$


is simply the necessary first-order condition of such a minimum. Note, also, that our "word of caution" translates to the following observation. Since the terminal cost-minimization condition characterizes competitive efficiency, and Hartwick's Rule is only the first-order necessary condition of this minimization, it cannot identify competitive efficiency.

\section{Proposition 4.1:}

Let $(\mathrm{z}(\mathrm{t}), \mathrm{k}(\mathrm{t}), \mathrm{p}(\mathrm{t}), \mathrm{q}(\mathrm{t}))$ be an interior competitive path which is efficient. Then for a.e. $\mathrm{T}>0$,

$$
\mathrm{p}(\mathrm{T}) \mathrm{k}(\mathrm{T}) \leq \mathrm{p}(\mathrm{T}) \mathrm{k}
$$

for all $k \in A \equiv\{K:$ there is a program $\hat{z}(t), \hat{k}(t))$ from $K$ satisfying $u \hat{(z}(t), \hat{k}(t)) \geq u(z(t+T)$, $\mathrm{k}(\mathrm{t}+\mathrm{T}))$ for a.e. $\mathrm{t} \geq 0\}$

Proof: Pick any $\mathrm{T}>0$. Suppose, contrary to (4.1), there is $\mathrm{k} \in \mathrm{A}$, such that

$$
\mathrm{p}(\mathrm{T}) \mathrm{k}(\mathrm{T})>\mathrm{p}(\mathrm{T}) \mathrm{k}
$$

Denote $[\mathrm{k}(\mathrm{T})-\mathrm{k}]$ by h. Then $\mathrm{p}(\mathrm{T}) \mathrm{h}>0$.

\section{Step 1:}

Denote $\left\|\mathrm{u}_{1}(\mathrm{z}(\mathrm{T}), \mathrm{k}(\mathrm{T}))\right\|$ by $\mathrm{B}^{\prime}$; let $\mathrm{M}^{\prime}$ be the maximum value of $-\left[\mathrm{V}^{\prime} \mathrm{F}(\mathrm{z}(\mathrm{T}), \mathrm{k}(\mathrm{T})) \mathrm{V}\right]$ among all $\mathrm{V}=(\mathrm{a}, \mathrm{b}) \in \mathbb{R}^{\mathrm{n}} \times \mathbb{R}^{\mathrm{n}}$ satisfying $\|\mathrm{V}\| \leq 1$, where $\mathrm{F}(\mathrm{z}(\mathrm{T}), \mathrm{k}(\mathrm{T}))$ is the Hessian of $\mathrm{u}$, evaluated at $(\mathrm{z}(\mathrm{T}), \mathrm{k}(\mathrm{T}))$. Let $(\mathrm{B}, \mathrm{M})>>\left(\mathrm{B}^{\prime}, \mathrm{M}^{\prime}\right)$.

Pick $\theta>0$, such that for all $(\mathrm{k}, \mathrm{z})$ satisfying $\|\mathrm{z}-\mathrm{z}(\mathrm{T}), \mathrm{k}-\mathrm{k}(\mathrm{T})\| \leq \theta,(\mathrm{z}, \mathrm{k}) \in$ int $\Omega$, and

(i) $\quad-\left[\mathrm{V}^{\prime} \mathrm{F}(\mathrm{z}, \mathrm{k}) \mathrm{V}\right] \leq 2 \mathrm{M}$ for all $\mathrm{V}=(\mathrm{a}, \mathrm{b}) \in \mathbb{R}^{\mathrm{n}} \times \mathbb{R}^{\mathrm{n}}$ satisfying $\|\mathrm{V}\| \leq 1$;

(ii) $\quad\left\|\mathrm{u}_{1}(\mathrm{z}, \mathrm{k})\right\| \leq 2 \mathrm{~B}$

\section{Step 2:}

Using the continuity of $(\mathrm{z}(\mathrm{t}), \mathrm{k}(\mathrm{t}), \mathrm{p}(\mathrm{t}), \mathrm{q}(\mathrm{t}))$ at $\mathrm{t}=\mathrm{T}$, we can find $0<\mathrm{S}<\mathrm{T}$, such that for 
all $\mathrm{t} \in[\mathrm{S}, \mathrm{T}]$,

(i) $\quad\|\mathrm{z}(\mathrm{t})-\mathrm{z}(\mathrm{T}), \mathrm{k}(\mathrm{t})-\mathrm{k}(\mathrm{T})\| \leq \theta / 4$

(ii) $\quad\left\|\mathrm{u}_{2}(\mathrm{z}(\mathrm{t}), \mathrm{k}(\mathrm{t}))\right\|\|\mathrm{h}\|(\mathrm{T}-\mathrm{S})<(1 / 4)[\mathrm{p}(\mathrm{T}) \mathrm{h} / \mathrm{q}(\mathrm{T})]$

(iii) $\quad[p(t) h / q(t) \geq(3 / 4)[p(T) h / q(T)]$

\section{Step 3:}

Let $0<\lambda<1$, with $\lambda$ sufficiently close to zero, so that

(i) $\left[\lambda^{1 / 4}\|\mathrm{~h}\| /(\mathrm{T}-\mathrm{S})\right][1+(\mathrm{T}-\mathrm{S})] \leq \theta / 4$; (ii) $2 \theta^{2} \lambda^{1 / 2} \mathrm{M}<\mathrm{p}$ (T) h q(T)/ (T-S)

Define the function $\left(\mathrm{z}^{\prime}(\mathrm{t}), \mathrm{k}^{\prime}(\mathrm{t})\right)$ from $\mathrm{k}(0)$ by:

$$
\begin{aligned}
& \mathrm{z}^{\prime}(\mathrm{t})=\mathrm{z}(\mathrm{t}) \text { for } 0 \leq \mathrm{t}<\mathrm{S} \\
& \mathrm{z}^{\prime}(\mathrm{t})=\mathrm{z}(\mathrm{t})-\lambda \mathrm{h} /(\mathrm{T}-\mathrm{S}) \text { for } \mathrm{t} \in[S, T] \\
& \mathrm{z}^{\prime}(\mathrm{t})=(1-\lambda) \mathrm{z}(\mathrm{t})+\lambda \hat{z}(\mathrm{t}-\mathrm{T}) \text { for } \mathrm{t}>\mathrm{T} \\
& \mathrm{k}^{\prime}(\mathrm{t})=\int_{0}^{\mathrm{t}} \mathrm{z}^{\prime}(\mathrm{s}) \text { ds for } \mathrm{t} \geq 0
\end{aligned}
$$

and

We can check that $\left(z^{\prime}(t), k^{\prime}(t)\right)$ is a program from $k(0)$. First, note that $k^{\prime}(t)=k(t)$ for $0 \leq \mathrm{t} \leq \mathrm{S}$. For $\mathrm{t} \in[\mathrm{S}, \mathrm{T}]$, we have

$$
\mathrm{k}^{\prime}(\mathrm{t})=\int_{0}^{\mathrm{t}} \mathrm{z}^{\prime}(\mathrm{s}) \mathrm{ds}=-\int_{\mathrm{S}}^{\mathrm{t}} \lambda \mathrm{h} /(\mathrm{T}-\mathrm{S}) \mathrm{ds}+\int_{0}^{\mathrm{t}} \mathrm{z}(\mathrm{s}) \mathrm{ds}=-[\lambda \mathrm{h}(\mathrm{t}-\mathrm{S}) /(\mathrm{T}-\mathrm{S})]+\mathrm{k}(\mathrm{t})
$$

Thus, for $\mathrm{t} \in[\mathrm{S}, \mathrm{T}]$, we have $\left\|\mathrm{z}^{\prime}(\mathrm{t})-\mathrm{z}(\mathrm{t}), \mathrm{k}^{\prime}(\mathrm{t})-\mathrm{k}(\mathrm{t})\right\|=[\lambda\|\mathrm{h}\| /(\mathrm{T}-\mathrm{S})][1+(\mathrm{t}-\mathrm{S})] \leq \lambda^{3 / 4}(\theta / 4) \leq(\theta / 4)$ by (4.3), so that by using Step 2 (i), we have $\left\|z^{\prime}(t)-z(T), k^{\prime}(t)-k(T)\right\| \leq \theta$ for $t \in[S, T]$ and consequently $\left(\mathrm{z}^{\prime}(\mathrm{t}), \mathrm{k}^{\prime}(\mathrm{t})\right) \in$ int $\Lambda$ by Step 1 . Further $\mathrm{k}^{\prime}(\mathrm{T})=\mathrm{k}(\mathrm{T})-\lambda \mathrm{h}=\mathrm{k}(\mathrm{T})-\lambda[\mathrm{k}(\mathrm{T})-\mathrm{k}]=(1-$

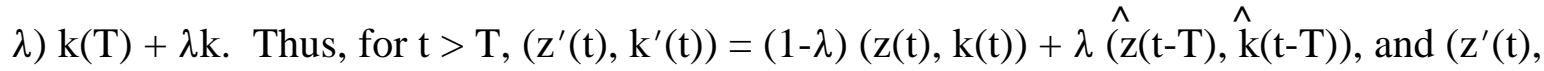
$\left.\mathrm{k}^{\prime}(\mathrm{t})\right) \in \Lambda$ by convexity of $\Lambda$.

\section{Step 4:}


Clearly for $0 \leq \mathrm{t}<\mathrm{S}$, we have $\mathrm{u}\left(\mathrm{z}^{\prime}(\mathrm{t}), \mathrm{k}^{\prime}(\mathrm{t})\right)=\mathrm{u}(\mathrm{z}(\mathrm{t}), \mathrm{k}(\mathrm{t}))$. And, for $\mathrm{t}>\mathrm{T}$, we have $\mathrm{u}\left(\mathrm{z}^{\prime}(\mathrm{t}), \mathrm{k}^{\prime}(\mathrm{t})\right) \geq(1-\lambda) \mathrm{u}(\mathrm{z}(\mathrm{t}), \mathrm{k}(\mathrm{t}))+\lambda \hat{\mathrm{u}}(\mathrm{z}(\mathrm{t}-\mathrm{T}), \hat{\mathrm{k}}(\mathrm{t}-\mathrm{T})) \geq \mathrm{u}(\mathrm{z}(\mathrm{t}), \mathrm{k}(\mathrm{t}))$.

We will now show that for $t \in[S, T]$, we have

$$
\mathrm{u}\left(\mathrm{z}^{\prime}(\mathrm{t}), \mathrm{k}^{\prime}(\mathrm{t})\right)>\mathrm{u}(\mathrm{z}(\mathrm{t}), \mathrm{k}(\mathrm{t}))
$$

which will establish that $(\mathrm{z}(\mathrm{t}), \mathrm{k}(\mathrm{t}))$ is inefficient. This contradiction will prove (4.1).

For $\mathrm{t} \in[\mathrm{S}, \mathrm{T}]$, we calculate

$$
\begin{aligned}
\mathrm{u}\left(\mathrm{z}^{\prime}(\mathrm{t}), \mathrm{k}^{\prime}(\mathrm{t})\right)-\mathrm{u}(\mathrm{z}(\mathrm{t}), \mathrm{k}(\mathrm{t}))=\mathrm{u}_{1}(\mathrm{z}(\mathrm{t}), \mathrm{k}(\mathrm{t}))\left(\mathrm{z}^{\prime}(\mathrm{t})-\mathrm{z}(\mathrm{t})\right) \\
+\mathrm{u}_{2}(\mathrm{z}(\mathrm{t}), \mathrm{k}(\mathrm{t}))\left(\mathrm{k}^{\prime}(\mathrm{t})-\mathrm{k}(\mathrm{t})\right)+(1 / 2) \mathrm{V}^{\prime}(\mathrm{t}) \tilde{\mathrm{F}}(\tilde{\mathrm{z}}(\mathrm{t}), \tilde{\mathrm{k}}(\mathrm{t})) \mathrm{V}(\mathrm{t})
\end{aligned}
$$

where $\mathrm{V}(\mathrm{t})=\left(\mathrm{z}^{\prime}(\mathrm{t})-\mathrm{z}(\mathrm{t}), \mathrm{k}^{\prime}(\mathrm{t})-\mathrm{k}(\mathrm{t})\right)$ and $\left.\tilde{\mathrm{z}}(\mathrm{t}), \tilde{\mathrm{k}}(\mathrm{t})\right)$ is a convex combination of $(\mathrm{z}(\mathrm{t}), \mathrm{k}(\mathrm{t}))$ and $\left(\mathrm{z}^{\prime}(\mathrm{t}), \mathrm{k}^{\prime}(\mathrm{t})\right)$ as given by Taylor's expansion.

Note that since $\left\|z^{\prime}(t)-z(T), k^{\prime}(t)-k(T)\right\| \leq \theta$ (by Step 3) and $\|\mathrm{z}(\mathrm{t})-\mathrm{z}(\mathrm{T}), \mathrm{k}(\mathrm{t})-\mathrm{k}(\mathrm{T})\| \leq \theta$ (by Step 2), we have $\|\tilde{\mathrm{z}}(\mathrm{t})-\mathrm{z}(\mathrm{T}), \tilde{\mathrm{k}}(\mathrm{t})-\mathrm{k}(\mathrm{T})\| \leq \theta$. Thus $\tilde{(\mathrm{z}}(\mathrm{t}), \tilde{\mathrm{k}}(\mathrm{t})) \in$ int $\Lambda$, and $-\left[\mathrm{V}^{\prime} \mathrm{F}(\tilde{\mathrm{z}}(\mathrm{t}), \tilde{\mathrm{k}}(\mathrm{t})) \mathrm{V}\right]$ $\leq 2 \mathrm{M}$ for all $\mathrm{V}=(\mathrm{a}, \mathrm{b})$ in $\mathbb{R}^{\mathrm{n}} \times \mathbb{R}^{\mathrm{n}}$ satisfying $\|\mathrm{V}\| \leq 1$.

Now $\|\mathrm{V}(\mathrm{t})\| \leq \lambda\|\mathrm{h}\|[1+(\mathrm{T}-\mathrm{S})] /(\mathrm{T}-\mathrm{S}) \leq \lambda^{3 / 4}(\theta / 4)$ for $\mathrm{t} \in[\mathrm{S}, \mathrm{T}]$, so that $\left\|\mathrm{V}(\mathrm{t}) / \theta \lambda^{3 / 4}\right\| \leq(1 / 4)<$ 1 , and so

$$
-\left[\mathrm{V}^{\prime}(\mathrm{t}) \mathrm{F}(\tilde{\mathrm{z}}(\mathrm{t}), \tilde{\mathrm{k}}(\mathrm{t})) \mathrm{V}(\mathrm{t})\right] \leq\left(\theta^{2} \lambda^{3 / 2}\right) 2 \mathrm{M}
$$

Also, $\left\|\mathrm{k}^{\prime}(\mathrm{t})-\mathrm{k}(\mathrm{t})\right\| \leq \lambda\|\mathrm{h}\|$ by Step 3, so $\left|\mathrm{u}_{2}(\mathrm{z}(\mathrm{t}), \mathrm{k}(\mathrm{t}))\left(\mathrm{k}^{\prime}(\mathrm{t})-\mathrm{k}(\mathrm{t})\right)\right| \leq \| \mathrm{u}_{2}\left(\mathrm{z}(\mathrm{t}), \mathrm{k}(\mathrm{t})\|\| \mathrm{k}^{\prime}(\mathrm{t})-\right.$ $\mathrm{k}(\mathrm{t}) \|<(\lambda / 4)[\mathrm{p}(\mathrm{T}) \mathrm{h} / \mathrm{q}(\mathrm{T})] /(\mathrm{T}-\mathrm{S})$ by Step 2 (ii).

Finally, $\mathrm{u}_{1}(\mathrm{z}(\mathrm{t}), \mathrm{k}(\mathrm{t}))\left(\mathrm{z}^{\prime}(\mathrm{t})-\mathrm{z}(\mathrm{t})\right)=-\left[\mathrm{p}(\mathrm{t})\left(\mathrm{z}^{\prime}(\mathrm{t})-\mathrm{z}(\mathrm{t})\right) / \mathrm{q}(\mathrm{t})\right]=[\mathrm{p}(\mathrm{t}) / \mathrm{q}(\mathrm{t})][\lambda \mathrm{h} /(\mathrm{T}-\mathrm{S})] \geq(3 \lambda / 4)$ $[\mathrm{p}(\mathrm{T}) \mathrm{h} / \mathrm{q}(\mathrm{t})] /(\mathrm{T}-\mathrm{S})$, by Step 2 (iii). Thus, we have $\mathrm{u}_{1}(\mathrm{z}(\mathrm{t}), \mathrm{k}(\mathrm{t}))\left(\mathrm{z}^{\prime}(\mathrm{t})-\mathrm{z}(\mathrm{t})\right)+\mathrm{u}_{2}(\mathrm{z}(\mathrm{t}), \mathrm{k}(\mathrm{t}))\left(\mathrm{k}^{\prime}(\mathrm{t})-\mathrm{k}(\mathrm{t})\right) \geq(\lambda / 2)[\mathrm{p}(\mathrm{T}) \mathrm{h} / \mathrm{q}(\mathrm{T})] /(\mathrm{T}-\mathrm{S})$

Using (4.6) and (4.7) in (4.5), $\mathrm{u}\left(\mathrm{z}^{\prime}(\mathrm{t}), \mathrm{k}^{\prime}(\mathrm{t})\right)-\mathrm{u}(\mathrm{z}(\mathrm{t}), \mathrm{k}(\mathrm{t})) \geq(\lambda / 2)[\mathrm{p}(\mathrm{T}) \mathrm{h} / \mathrm{q}(\mathrm{T})] /(\mathrm{T}-\mathrm{S})$ - 
$\theta^{2} \lambda^{3 / 2} \mathrm{M}=(\lambda / 2)\left([\mathrm{p}(\mathrm{T}) \mathrm{h} / \mathrm{q}(\mathrm{T})(\mathrm{T}-\mathrm{S})]-\theta^{2} \lambda^{1 / 2} 2 \mathrm{M}\right)>0$ by (4.3) (ii). $\quad / /$

\section{Theorem 4.1:}

Let $(\mathrm{z}(\mathrm{t}), \mathrm{k}(\mathrm{t}), \mathrm{p}(\mathrm{t}), \mathrm{q}(\mathrm{t}))$ be an interior competitive path, which is efficient and equitable. Then

$$
\mathrm{p}(\mathrm{t}) \mathrm{z}(\mathrm{t})=0 \quad \text { for a.e. } \mathrm{t} \geq 0
$$

Proof: Pick any $\mathrm{T}>0$ at which $\mathrm{k}$ is differentiable (as a function of $\mathrm{t}$ ) and at which $\mathrm{z}$ is

continuous (as a function of $\mathrm{t}$ ). The complement of this set of $\mathrm{T}$ in $[0, \infty$ ) has Lebesgue measure zero.

Pick $\mathrm{S}>\mathrm{T}$, and note that $\mathrm{k}_{\mathrm{S}}$ is in $\mathrm{A}$, where $\mathrm{A}$ is defined in Proposition 4.1, since the given path is equitable. Thus, using Proposition 4.1,

$$
\mathrm{p}(\mathrm{T})(\mathrm{k}(\mathrm{T})-\mathrm{k}(\mathrm{S})) \leq 0
$$

This implies that since $\mathrm{S}>\mathrm{T}$,

$$
\mathrm{p}(\mathrm{T})[\mathrm{k}(\mathrm{S})-\mathrm{k}(\mathrm{T})] /(\mathrm{S}-\mathrm{T}) \geq 0
$$

Letting, $\mathrm{S} \rightarrow \mathrm{T}$, and noting that $\mathrm{k}$ is differentiable at $\mathrm{T}$, we have

$$
\mathrm{p}(\mathrm{T}) \mathrm{z}(\mathrm{T})=\mathrm{p}(\mathrm{T}) \dot{\mathrm{k}}(\mathrm{T}) \geq 0
$$

Pick $0<\mathrm{s}<\mathrm{T}$ and note that $\mathrm{k}_{\mathrm{s}}$ is in $\mathrm{A}$, where $\mathrm{A}$ is defined in Proposition 4.1, since the given path is equitable. Thus, using the Proposition,

$$
\mathrm{p}(\mathrm{T})(\mathrm{k}(\mathrm{T})-\mathrm{k}(\mathrm{s})) \leq 0
$$

This implies that since $\mathrm{s}<\mathrm{T}$,

$$
\mathrm{p}(\mathrm{T})[\mathrm{k}(\mathrm{T})-\mathrm{k}(\mathrm{s})] /(\mathrm{T}-\mathrm{s}) \leq 0
$$

Letting $\mathrm{s} \rightarrow \mathrm{T}$, and noting that $\mathrm{k}$ is differentiable at $\mathrm{T}$, we have 


$$
\mathrm{p}(\mathrm{T}) \mathrm{z}(\mathrm{T})=\mathrm{p}(\mathrm{T}) \dot{\mathrm{k}}(\mathrm{T}) \leq 0
$$

Combining (4.10) and (4.12), we get (4.8). // 


\section{References}

[1] Aronsson, T., Johansson, P.-O., Löfgren, K.-G., (1995), Investment decisions, future consumption and sustainability under optimal growth, Umeå Economic Studies No. 371, University of Umeå.

[2] Burmeister, E. and P.J. Hammond, (1977), Maximin paths of heterogeneous capital accumulation and the instability of paradoxical steady states, Econometrica, 45, 853-870.

[3] Burmeister, E., Turnovsky, S.J. (1972), Capital deepening response in an economy with heterogeneous capital goods, American Economic Review, 62, 842-853.

[4] Cass, D., (1965), Optimum growth in an aggregative model of capital accumulation, Rev. of Econ. Stud., 32, 233-240.

[5] Cass, D., (1972), On capital over-accumulation in the aggregative neo-classical model of economic growth: A complete characterization, J. Econ. Theory, 4, 200-223.

[6] Cass, D., Mitra, T., (1991), Indefinitely sustained consumption despite exhaustible natural resources, Econ. Theory, 1, 119-146.

[7] Cass, D., Shell, K., (1976), The structure and stability of competitive dynamical systems, J. Econ. Theory, 12, 31-70.

[8] Dasgupta, P.S., Heal, G.M., (1974), The optimal depletion of exhaustible resources, Rev. of Econ. Stud., Symposium on the Economics of Exhaustible Resources, 41, 3-28.

[9] Dasgupta, P.S., Heal, G.M., (1979), Economic Theory and Exhaustible Resources, Cambridge University Press, Cambridge.

[10] Dasgupta, S., Mitra, T., (1983), Intergenerational equity and efficient allocation of exhaustible resources, International Econ. Rev., 24, 133-153.

[11] Dixit, A., P. Hammond and M. Hoel, “On Hartwick's Rule for Regular Maximin Paths of Capital Accumulation and Resource Depletion”, Review of Economic Studies, 47 (April, 1980), 551-556.

[12] Dorfman, R., Samuelson, P., Solow, R., (1958), Linear Programming and Economic Analysis, McGraw-Hill. 
[13] Hamilton, K., (1995), Sustainable development, the Hartwick rule and optimal growth, Environmental and Resource Economics, 5, 393-411.

[14] Hartwick, J.M. (1977), Intergenerational equity and investing of rents from exhaustible resources, Am.Ec. Rev., 66, 972-974.

[15] Koopmans, T.C., (1965), On the concept of optimal economic growth, Pontificae Academia Scientiarum, Vatican City, 225-288.

[16] Majumdar, M., (1972), Some general theorems on efficiency prices with an infinite dimensional commodity space, J. Econ. Theory, 5, 1-13.

[17] Malinvaud, E., (1953), Capital accumulation and efficient allocation of resources, Econometrica, 21, 233-268.

[18] Solow, R.M., (1974), Intergeneraitonal equity and exhaustible resources, Rev. of Econ. Stud., Symposium on the Economics of Exhaustible Resources, 41, 29-45.

[19] Solow, R.M., (1986), On the intergenerational allocation of natural resources, Scand. J. of Economics, 88, 141-149.

[20] Solow, R.M., (1992), An almost practical step towards sustainability, Washington, D.C.: Resources for the Future. 


\section{ENDNOTES}

1. For $\mathrm{x}, \mathrm{y}$ in $\mathbb{R}^{\mathrm{n}}, \mathrm{x} \geq \mathrm{y}$ means $\mathrm{x}_{\mathrm{i}} \geq \mathrm{y}_{\mathrm{i}}$ for $\mathrm{i}=1, \ldots \mathrm{n} ; \mathrm{x}>\mathrm{y}$ means $\mathrm{x} \geq \mathrm{y}$ and $\mathrm{x} \neq \mathrm{y} ; \mathrm{x}>>\mathrm{y}$ means $\mathrm{x}_{\mathrm{i}}>\mathrm{y}_{\mathrm{i}}$ for $\mathrm{i}=1, \ldots, n$. For $\mathrm{x}$ in $\mathbb{R}^{\mathrm{n}}$, the sum norm of $\mathrm{x}$, denoted by $\|\mathrm{x}\|$ is defined by $\|\mathrm{x}\|=\sum_{\mathrm{i}=1}^{\mathrm{n}}\left|\mathrm{x}_{\mathrm{i}}\right|$.

2. We are using conventional notation: $\dot{x}$ means time derivative of $x$. So if $x(t)$ is a vector valued function, i.e., $x(t)=\left(x_{1}(t), \ldots, x_{n}(t)\right)$, then $\dot{x}(t)=\left[d_{1} / d t, \ldots ., d x_{n} / d t\right]$. If $x$ is a vector $\left(\mathrm{x}_{1}, \ldots, \mathrm{x}_{\mathrm{n}}\right)$ and $\mathrm{f}(\mathrm{x})$ is a vector valued function defined from $\mathbb{R}^{\mathrm{n}}$ to $\mathbb{R}^{\mathrm{m}}$, that is,

$f(x)=\left(\left(f_{1}(x), \ldots, f_{m}(x)\right)\right.$, then $f^{\prime}(x)$ is the $m \times n$ matrix whose $i j^{\text {th }}$ element is $\left(\partial f_{i}(x) / \partial x_{j}\right)$. If

$f: \mathbb{R}^{n} \rightarrow \mathbb{R}$, then $f_{i}$ is the $i^{\text {th }}$ partial derivative of $f$ and $f_{i j}$ is the $j^{\text {th }}$ partial derivative of

$f_{i}, i=1, \ldots, n, j=1, \ldots, n$. The notation "a.e." stands for "almost everywhere"; more precisely, if $A$ is a subset of $\mathbb{R}$, then by the expression "for $t \in A$, a.e." we mean "for $t \in B$, where $B$ is a subset of A such that the complement of B in A is a set of Lebesgue measure zero"; if the set $A$ is an interval $[a, \infty)$ we often use the expression "for $t \geq a$, a.e." in place of "for $t$ $\epsilon[a, \infty)$, a.e.". 